\title{
Body composition in coronary artery disease in KONKAN region of India-Is non- obesity an indicator of Coronary Artery Disease?
}

\author{
Patil Suvarna $N^{l}$, Shamraj Pranav ${ }^{l}$, Joglekar Charudatta $V^{2}$, Bhalerao Amitkumar ${ }^{l}$, Nanaware Sagarl, \\ Deshpande Janhavi ${ }^{1}$, Paranjpe Amey ${ }^{1}$, Jadhav Dnyaneshwar A², Dervankar Omkar A ${ }^{2}$

\begin{abstract}
${ }^{1}$ Department of Medicine, BKL Walawalkar Hospital and Rural Medical College, Sawarde, Chiplun, Ratnagiri, Maharashtra, India

${ }^{2}$ Statistics Unit, Regional Centre for Adolescent Health and Nutrition, BKL Walawalkar Hospital and Rural Medical College, Taluka-Chiplun, District-Ratnagiri, Maharashtra, India
\end{abstract}

\begin{abstract}
Background: India is witnessing a rising prevalence of non-communicable diseases like diabetes, hypertension, coronary artery disease. This is attributed to rapid nutrition and lifestyle transition taking place since last 2 decades. Obesity is a well-known independent risk factor but very little information is available about role of leanness (low $\mathrm{BMI})$. We investigated whether non-obesity could be an independent risk factor for Coronary artery disease in a rural clinic in KONKAN. Methods: In a cross-sectional study we studied body composition of 300 patients (207 men) who underwent Coronary angiography in a rural hospital in KONKAN region. History of diabetes, hypertension and history of smoking, tobacco chewing was recorded. Body composition was estimated using bio-impedance analyser. Based on results of coronary angiography, we generated a SYNTAX score derived by number of vessels involved and classified them into groups of severity of coronary artery disease (CAD). Results: There were 95 (31\%) diabetes and $189(63 \%)$ hypertensive patients in the sample and $60 \%$ of them smoked or chewed tobacco. There were $43(28$ males) patients with SYNTAX score of zero. Among those with coronary artery disease $(n=257)$ increasing severity of CAD was associated with lower body weight, BMI, body fat percentage, and body fat mass and ejection fraction as against positive trend for lean mass and visceral fat. Conclusion: BMI, fat mass decreased with severity of CAD while lean mass and visceral fat increased. We observed high proportion of CAD in underweight and lean KONKAN adults. These findings need further investigations.
\end{abstract}

KEYWORDS: Cardiology; Epidemiology; Konkan region

\section{INTRODUCTION}

A 11 over the world Coronary artery disease (CAD) is one of the frequent types of diseases in general [1]. Incidence of CAD is known to be linked with obesity, hypertension, diabetes, smoking, exercise, diet, cholesterol, and depression as stated by the American Heart association and American college of cardiology [2]. Obesity is a well-established independent risk factor for coronary artery disease (CAD) along with numerous other co-morbidities such as hypertension, type 2 diabetes, dyslipidemia and certain cancers $[2,3,4]$. Underweight i.e., body mass index (BMI) below $18.5 \mathrm{~kg} / \mathrm{m} 2$ or non- obesity (BMI within normal range), has not been an object of concern. Confirmed improvement in prevailing cardiovascular risk factors like hypertension, diabetes, dyslipidemia and mortality from CAD after weight loss has been reported $[5,6]$. Paradoxically survival benefit was also perceived in few more studies presenting better clinical results in overweight and obese patients treated for CVDs when compared with normal weight patients $[7,8]$. Disease biology leading to term "obesity paradox" is uncertain where obesity was principally calculated using only BMI to exemplify obesity in these studies [9].

When Adjoining villages were studied by us for

Correspondence: Dr Suvarna Patil, Medical Director, BKL Walawalkar Rural Medical College Sawarde, Chiplun, District-Ratnagiri, Maharashtra, India. E-mail: dr.suvarnanpatil@gmail.com

$\begin{array}{ll} & \\ \text { eISSN: 2395-0471 } & \text { (C) Authors; 2021. (CC BY-NC-SA 4.0) } \\ \text { pISSN: 2521-0394 } & \text { This is an Open Access article which permits unrestricted } \\ \text { Don-commercial use, provided the original work is properly cited. }\end{array}$


BMI in adults it was discerned that, only $4.5 \%$ were overweight and $51.8 \%$ were underweight having BMI $<18.5 \mathrm{~kg} / \mathrm{m} 2$ [10]. In another study by us there was high occurrence (64\%) of thinness in adolescent girls from rural schools of Konkan. Body composition of diabetic people of Konkan was tested by us earlier and it showed appreciably low body fat \%, visceral fat, basal metabolic rate with higher muscle mass\% when compared with overweight counterparts [10].

We decided to study the body composition in patients with CAD and investigated whether nonobesity is an independent risk factor for CAD in a hospital based cross-sectional study.

\section{Material And Methodology}

Study design: Cross sectional observational study

Ethics: Informed and written consent was obtained from all the subjects to use the data. Ethical approval from the institute ethics committee for the data analysis was also obtained. Our institute ethics committee is registered with the government of India. Registration number is EC/755/INST/MH/2015/RR-18.

Study time frame: The study was conducted from February 2019 to March 2020.

Study location: BKL Walawalkar Hospital and Rural Medical College, Sawarde, Chiplan

Study population: This study was conducted among the patients who underwent coronary angiography (CAG) at our Hospital. Patients underwent CAG using a standard clinical technique with either a femoral artery or radial artery approach [11].

Inclusion criteria: Patients with a history of chest pain, angina, stable angina, ST elevation and non-ST acute coronary syndrome were included

Exclusion criteria: those with chronic illnesses like acute or chronic renal failure, thyroid disorders, acute infections, stroke, and diabetic keto-acidosis were excluded.

\section{Methodology:}

Patient's demographic profile, socioeconomic status, habits (smoking and or tobacco chewing) was recorded.

All patients received long-term treatment as per standard protocols. The CAG was performed and reported by interventional cardiologists. Coronary artery disease was defined as any degree of stenosis in the major coronary arteries. CAD was graded according to the number of involved vessels: no CAD, single vessel disease (SVD), double vessels disease (DVD), triple vessels disease (TVD) etc. [12]. Assessment of
Severity of CAD was done using SYNTAX score available online. The SYNTAX score considers complex lesions counting bifurcations, chronic total occlusions, thrombus, calcification, and small diffuse disease. The score ranges from 0 to greater than 60 in very complex coronary anatomy lesions [13]. In principle, the SYNTAX score is the sum of the points assigned to each individual lesion identified in the coronary tree with $>50 \%$ narrowing in the diameter of the vessels that measure greater than $1.5 \mathrm{~mm}$. The percentage of stenosis was not a consideration.

Presence of stenosis from 50-99\% in diameter, narrowing of less than $50 \%$ in diameter or total occlusion were considered.

We also measured body composition (Fat mass, lean mass, bone mass and basal metabolic rate (BMR) of the patients using bio-impedance analyser (MC-420) (TANITA corporation, Japan). We also noted the presence of diabetes (DM) and hypertension (HN) in our subjects.

\section{Statistical methods}

Data has been represented as mean (standard deviation) for continuous variables and frequency (percentage) for categorical variables. Patients with SYNTAX score of 0 are referred as those without $\mathrm{CAD}$ and those with score $>0$ are referred as those with CAD. We created two subgroups of patients, those without CAD and those with CAD. Comparison between the two subgroups was done by independent $t$ test for continuous variables and by chi square test for categorical variables. We also created sex specific quartiles of SYTAX score for those with CAD. Thus, those in the upper quartile are patients with severe CAD. We compared anthropometric and body composition parameters across the quartiles using trend test and adjusted it for age. We used SPSS 25.0 (SPSS Inc, Chicago, IL, USA) for the analysis.

\section{RESUlts}

Total of 300 patients underwent CAG. Of these 43 patients had a SYNTAX score of 0 thus they were without CAD and the remaining 257 had $\mathrm{CAD}$ of varying severity.

We performed the statistical analysis of the two groups of patients, those without and those with CAD (Table 1) and found that with the exception of ejection fraction which was higher in those without CAD all other parameters were statistically similar.

When we excluded patients without CAD $(n=43)$ from the study population $(n=300)$ and divided the sample of those with CAD $(n=257)$ into sex specific quartiles. 
Table 1: Anthropometric parameters in relation to absence or presence of CAD

\begin{tabular}{|l|c|c|c|}
\hline \multicolumn{1}{|c|}{$\begin{array}{c}\text { Para- } \\
\text { meters }\end{array}$} & $\begin{array}{c}\text { Syntax } \\
\text { score }=0 \\
(\mathrm{n}=43)\end{array}$ & $\begin{array}{c}\text { Syntax } \\
\text { score }>0 \\
(\mathrm{n}=237)\end{array}$ & $\begin{array}{c}\text { P } \\
\text { value }\end{array}$ \\
\hline Male/Female & $28 / 15$ & $179 / 78$ & 0.552 \\
\hline Age (years) & $60.6(10.7)$ & $60.6(11)$ & 0.991 \\
\hline Height (cm) & $157.8(9.8)$ & $158.2(10)$ & 0.803 \\
\hline Weight (Kg) & $59.2(11.3)$ & $57.5(11)$ & 0.371 \\
\hline BMI (Kg/m2) & $23.7(4.3)$ & $22.9(3.9)$ & 0.222 \\
\hline $\begin{array}{l}\text { Underweight + } \\
\text { Normal n (\%) }\end{array}$ & $31(72)$ & $189(73.6)$ & 0.84 \\
\hline Fat \% & $28.0(28.0)$ & $26.9(8.0)$ & 0.392 \\
\hline Fat mass (Kg) & $17.1(8.2)$ & $15.6(6.0)$ & 0.282 \\
\hline Muscle mass \% & $39.8(7.2)$ & $39.6(7.8)$ & 0.898 \\
\hline Visceral fat(level) & $10.6(3.7)$ & $10.4(4.2)$ & 0.659 \\
\hline Bone mass (Kg) & $2.2(0.4)$ & $2.2(0.5)$ & 0.538 \\
\hline Ejection Fraction & $55.7(11.4)$ & $46.4(46.4)$ & 0.003 \\
\hline DM n (\%) & $16(37.2)$ & $79(30.6)$ & 0.39 \\
\hline HTN n(\%) & $29(67.4)$ & $160(62.3)$ & 0.512 \\
\hline Table 2 CAD & & & \\
\hline
\end{tabular}

Table 2 : CAD severity and anthropometry, body composition

\begin{tabular}{|c|c|c|c|c|c|}
\hline \multirow{2}{*}{$\begin{array}{l}\text { Para- } \\
\text { meters }\end{array}$} & \multicolumn{5}{|c|}{ Syntax Score Quartiles (sex specific) } \\
\hline & $\begin{array}{c}\mathrm{Q} 1 \\
\mathrm{n}=72\end{array}$ & $\begin{array}{c}\mathrm{Q} 2 \\
\mathrm{n}=60\end{array}$ & $\begin{array}{c}\text { Q3 } \\
\mathrm{n}=62\end{array}$ & $\begin{array}{c}\mathrm{Q} 4 \\
\mathrm{n}=63\end{array}$ & \multirow[t]{2}{*}{$\begin{array}{c}\mathrm{p}- \\
\text { value }\end{array}$} \\
\hline Range & $7-12$ & $12-15$ & $15-20$ & $20-39$ & \\
\hline $\begin{array}{l}\text { Age } \\
\text { (years) }\end{array}$ & $\begin{array}{c}59.9 \\
(12.4)\end{array}$ & $\begin{array}{c}58.8 \\
(10.9)\end{array}$ & $\begin{array}{c}61 \\
(11)\end{array}$ & $\begin{array}{l}62.5 \\
(9.2)\end{array}$ & 0.109 \\
\hline $\begin{array}{l}\text { Height } \\
(\mathrm{cm})\end{array}$ & $\begin{array}{l}158.6 \\
(10.6)\end{array}$ & $\begin{array}{l}156.8 \\
(10.4)\end{array}$ & $\begin{array}{c}159.6 \\
(9.4)\end{array}$ & $\begin{array}{c}158.1 \\
(9.8)\end{array}$ & 0.848 \\
\hline $\begin{array}{l}\text { Weight } \\
(\mathrm{Kg})\end{array}$ & $\begin{array}{c}59.5 \\
(11.4)\end{array}$ & $\begin{array}{c}55.0 \\
(10.5)\end{array}$ & $\begin{array}{c}57.5 \\
(12.8)\end{array}$ & $\begin{array}{l}57.4 \\
(9)\end{array}$ & 0.045 \\
\hline $\begin{array}{l}\text { BMI (Kg/ } \\
\text { m2) }\end{array}$ & $\begin{array}{l}23.7 \\
(4.6)\end{array}$ & $\begin{array}{l}22.4 \\
(3.6)\end{array}$ & $\begin{array}{l}22.4 \\
(3.8)\end{array}$ & $\begin{array}{l}21.8 \\
(3.2)\end{array}$ & 0.024 \\
\hline $\begin{array}{l}\text { Normal+ } \\
\text { Underweight } \\
\mathrm{N}(\%)\end{array}$ & $\begin{array}{c}51 \\
(70.8)\end{array}$ & $\begin{array}{c}46 \\
(76.7)\end{array}$ & $\begin{array}{c}44 \\
(70.9)\end{array}$ & $\begin{array}{c}48 \\
(76.1)\end{array}$ & 0.65 \\
\hline Fat \% & $\begin{array}{l}27.2 \\
(9.3) \\
\end{array}$ & $\begin{array}{l}26.9 \\
(7.8) \\
\end{array}$ & $\begin{array}{l}26.4 \\
(7.5) \\
\end{array}$ & $\begin{array}{l}26.0 \\
(7.4) \\
\end{array}$ & 0.04 \\
\hline $\begin{array}{l}\text { Fat mass } \\
(\mathrm{Kg})\end{array}$ & $\begin{array}{l}16.5 \\
(7.3)\end{array}$ & $\begin{array}{l}15.0 \\
(5.5)\end{array}$ & $\begin{array}{l}15.5 \\
(5.8)\end{array}$ & $\begin{array}{l}14.8 \\
(5)\end{array}$ & 0.03 \\
\hline $\begin{array}{l}\text { Muscle } \\
\text { mass \% }\end{array}$ & $\begin{array}{l}37.3 \\
(7.7)\end{array}$ & $\begin{array}{l}37.9 \\
(7.8)\end{array}$ & $\begin{array}{l}39.8 \\
(8.5)\end{array}$ & $\begin{array}{l}39.8 \\
(6.9)\end{array}$ & 0.05 \\
\hline $\begin{array}{l}\text { Lean } \\
\text { muscle } \\
\text { mass (kg) }\end{array}$ & $\begin{array}{l}41.0 \\
(8.1)\end{array}$ & $\begin{array}{l}40.3 \\
(8.1)\end{array}$ & $\begin{array}{l}42.0 \\
(9.0)\end{array}$ & $\begin{array}{l}42.8 \\
(7.4)\end{array}$ & 0.05 \\
\hline $\begin{array}{l}\text { Visceral } \\
\text { fat (level) }\end{array}$ & $\begin{array}{l}10.7 \\
(4.5)\end{array}$ & $\begin{array}{c}9.4 \\
(3.8)\end{array}$ & $\begin{array}{l}10.1 \\
(4.5)\end{array}$ & $\begin{array}{l}10.9 \\
(3.9)\end{array}$ & 0.05 \\
\hline $\begin{array}{c}\text { Bone } \\
\text { mass }(\mathrm{Kg})\end{array}$ & $\begin{array}{c}2.3 \\
(0.5)\end{array}$ & $\begin{array}{c}2.1 \\
(0.5)\end{array}$ & $\begin{array}{c}2.2 \\
(0.5)\end{array}$ & $\begin{array}{c}2.2 \\
(0.4)\end{array}$ & 0.07 \\
\hline BMR(Kcal) & 1163 & 1164 & 1146 & 1168 & 0.23 \\
\hline $\begin{array}{l}\text { Ejection } \\
\text { Fraction }\end{array}$ & 53.4 & 44.8 & 42.4 & 45 & 0.017 \\
\hline DM n (\%) & $20(28)$ & $17(28)$ & $19(31)$ & $23(37)$ & 0.27 \\
\hline HTN n(\%) & $43(60)$ & $40(67)$ & $34(55)$ & $43(68)$ & 0.58 \\
\hline
\end{tabular}

(Table-2)based upon the SYNTAX score, we found decreasing trend across CAD severity for weight, $\mathrm{BMI}$, fat $\%$, and fat mass $(\mathrm{p}<0.05$ adjusted for age). Ejection fraction also had decreasing trend. Decreasing trend for bone mass was marginal $(p=0.07)$. There was increasing trend for lean mass. Though prevalence of DM and HTN increased, trend was not statistically significant.

\section{Discussion}

We have measured various components of body composition parameters among patients who underwent CAG and were subsequently diagnosed with CAD of various severities based on the SYNTAX score.

In our study; BMI, fat mass, and bone mass had a decreasing trend but lean muscle mass and visceral fat had an increasing trend with increasing severity of CAD.

The contrary association between BMI and severity of CAD has been reported previously by Parsa and Jahanshahi [14]. The inverse relationship with obesity has also been reported by Rubinshtein et al [15]. In our study also we have found out some to be some protective effect of fat mass against CAD.

There has been an argument concerning link between obesity and coronary artery disease (CAD) for decades and it has been believed that high body mass index (BMI) is a risk factor for CAD [14]. Weight loss was showing improvement in pre-existing cardiovascular risk factors viz. hypertension (HTN), diabetes, dyslipidaemia, and mortality [15] but in our study more than 70 $\%$ patients were either normal or underweight.

The mechanisms leading to this phenomenon can be termed as "obesity paradox."

Indians amongst Asians are more susceptible to CAD at young age with a incidence of $5 \%$ to $10 \%$ [16]. For older CAD subjects conventional risk factors viz. smoking, diabetes, hypertension, obesity, and family history are more important [17]. The most associated risk factor in young CAD subjects is smoking. In our study $60 \%$ subjects smoked or chewed tobacco. In men it was higher $(70 \%)$. This is in tune with the epidemiological evidence showing higher incidence of CAD in men [18]. Cardiac mortality was positively associated with body mass index (BMI) in a Munster Heart Study [19]. Several protective mechanisms have been suggested by Jahangir et al [20] which include greater metabolic reserves, less cachexia, younger presenting age, increased muscle mass and strength, possible improved cardiorespiratory fitness despite obesity and diminished hormonal response including the renin-angiotensin-aldosterone system. We do not have any measures of these 
except body composition measurements. We also observed positive association of visceral fat levels with CAD severity. Bays $\mathrm{HE}$ et al [21] proposed that visceral adipose tissue is metabolically more active and pathological than subcutaneous adipose tissue inducing immune response which contributes to atherosclerotic cardiovascular disease.

There are major limitations to our study. Our study sample is a hospital based small sample which could be prone to selection bias. We have not measured any other cardiovascular risk factors.

There is considerable presence of malnutrition in people of Konkan in all stages of life. Our data shows high (34\%) prevalence of low birth weight in neonates [22], high incidence of stunting in adolescents [23] Our assessment of 2200 adjacent villages showed that $51.8 \%$ adults were underweight (BMI) below $<18.5 \mathrm{~kg} / \mathrm{m} 2$ and only $4.5 \%$ were overweight. Government survey of this region reported the prevalence of diabetes around $7 \%$, and $70 \%$ occurrence of leanness. This emphasised the fact that the overall population of KONKAN is lean [24]. In BRFSS -A Cross sectional study 2013 it was found that the underweight population had greater risk of $\mathrm{CAD}$ and mortality than obese when adjusted with covariates [25].

This emphasizes the fact there under nutrition is widespread in Konkan. Therefore, to study underweight CAD population becomes a promising problem.

\section{Conclusion}

Under weight, low fat mass and bone mass increases the severity of CAD, but better lean muscle mass and visceral fat decreases the severity of CAD in Konkan adults.

Usually, obesity is associated with CVD but in our hospital-based data from KONKAN population, we observed that there is a huge incidence of CVD in normal and underweight patients. This paradoxical finding needs to be studied further by epidemiological, genetic, and epigenetic studies and by carrying out studies on lifestyle modifications.

Acknowledgments: Faculty of cardiology and medicine departments, B.K.L. Walawalkar rural medical college. Our special thanks to Dr Sanjiv Patankar for the final editing of the manuscript.

Funding: The authors did not receive any grant from the funding agencies.

Disclaimer: The authors have no financial or proprietary interest in the subject matter of this article

Conflict of interest : Nil
Source of funding : Nil

\section{REFERENCES}

1. Ross R. The pathogenesis of atherosclerosis: a perspective for the 1990s. Nature. 1993;362:801-9

2. Drozda J, Messer JV, Spertus J. ACCF/ AHA/AMA-PCPI 2011 performance measures for adults with coronary artery disease and hypertension: a report of the American college of cardiology foundation/ American heart association task force on performance measures and the American medical association physician consortium for performance improvement. Circulation $.2011 ; 124: 248-70$

3. Malik VS, Willett WC, Hu FB. Global obesity: trends, risk factors and policy implications. Nat Rev Endocrinol. 2013;9:13-27

4. Grundy SM, Pasternak R, Greenland P. Assessment of cardiovascular risk by use of multiple-risk-factor assessment equations: a statement for healthcare professionals from the American Heart Association and the American College of Cardiology. Circulation. 1999; 100:1481-92

5. Artham SM, Lavie CJ, Milani V. Value of weight reduction in patients with cardiovascular disease. Current Treatment Options in Cardiovascular Medicine. 2010;12(1):21-35

6. Sierra-Johnson J, A. Romero-Corral, V. K. Somers et al. Prognostic importance of weight loss in patients with coronary heart disease regardless of initial body mass index. European Journal of Cardiovascular Prevention and Rehabilitatio. 2008;15 :33640

7. Lavie CJ, Milani RV, Ventura HO. Obesity and cardiovascular disease. risk factor, paradox, and impact of weight loss. Journal of the American College of Cardiology. 2009; 53:1925-32

8. Lavie CJ, Milani RV, Artham SM. The obesity paradox, weight loss, and coronary disease. American Journal of Medicine. 2009; 122:1106-14

9. Gregory AB, Lester KK, Gregory DM. The Relationship between Body Mass Index and the Severity of Coronary Artery Disease in Patients Referred for Coronary Angiography. Cardiol Res Pract. 2017; 5481671

10. Patil S, Kadam S, Desai M. Diabetes in KONKAN region of India. World $\mathrm{J}$ of Diabetes. 2019;10:37-46

11. Levine GN, Bates ER, Blankenship 
JC. ACCF/AHA/SCAI Guideline for percutaneous coronary intervention: a report of the American college of cardiology foundation/American heart association task force on practice guidelines and the society for cardiovascular angiography and interventions. Circulation. 2011;124:e574651

12. Shenoy V, Mehendale V, Prabhu K, et al. Correlation of serum homocysteine levels with the severity of coronary artery disease. Indian J Clin Biochem. 2014; 9:339-44

13. Marso SP. Revascularization Approaches. In Chronic Coronary Artery Disease: A Companion to Braunwald's Heart Disease Elsevier.2018;337-54

14. Parsa AF, Jahanshahi B. Is the relationship of body mass index to severity of coronary artery disease different from that of waist-to-hip ratio and severity of coronary artery disease? Paradoxical findings. Cardiovascular Journal of Africa. 2015;26:13-6.

15. Rubinshtein R, Halon DA. Relation between obesity and severity of coronary artery disease. Am J Cardiol. 2006;97:1277-80

16. Aggarwal A, Srivastava S, Velmurugan MV. Newer perspectives of coronary artery disease in young World J Cardiol. 2016;12:728-34

17. Lawton JS. Sex and Gender Differences in Coronary Artery Disease. Semin Thoracic Surg. 2011;23:126-30

18. 18. Schulte H, Cullen P, Assmann G. Obesity, mortality and cardiovascular disease in the Munster Heart Study (PROCAM). Atherosclerosis. 1999;144:199-209

19. Jahangir E., De Schutter A., Lavie C. J. The relationship between obesity and coronary artery disease. Translational Research. 2014;164:336-44.

20. Bays H, Ballantyne C. Adiposopathy: why do adiposity and obesity cause metabolic disease? Future Lipidol. 2006;1:389-420

21. Bays HE, Gonzalez-Campoy JM, Bray GA. Pathogenic potential of adipose tissue and metabolic consequences of adipocyte hypertrophy and increase visceral adiposity. Expert Rev Cardiovasc Ther. 2008;6:343-68

22. Patil S. Holistic antenatal care for rural areaschallenges and solutions. International Journal of Current Research June. 2017; 9(6);53151-3

23. Patil S, Joglekar C, Desai M. Nutritional Status and Psychological Impairment in Rural Adolescent Girls: Pilot Data From "KONKAN" Region of Western India. Front. Public Health June 2018;(6):1-6

24. Patil S, Kadam S, Desai M. Diabetes in KONKAN region of India. World $\mathrm{J}$ of Diabetes. 2019;10(1):37-46

25. Park D, Lee JH, Han S. Underweight: another risk factor for cardiovascular disease? A cross-sectional 2013 Behavioral Risk Factor Surveillance System (BRFSS) study of 491,773 individuals in the USA. Medicine (Baltimore). 2017;96:e8769 